\title{
The Natural Resource Management Implications of Rural Property Turnover
}

\author{
Emily Mendham $^{1,2}$, Allan Curtis ${ }^{1,2}$ and Joanne Millar ${ }^{2,3}$
}

\begin{abstract}
One aspect of recent rural change is in-migration, which is challenging the traditional dominance of production values in some areas. We explored the natural resource management implications of property turnover in two Australian regions. Our mixed-methods approach combined analysis of property sales records and spatially referenced landholder survey data with data from key informant interviews. Close to 50\% of rural properties are expected to change hands between 2006 and 2016, double the change in the previous decade. This change is linked to the transformation of these rural areas, including the influx of non-farming rural landholders seeking amenity values. Our research suggests that property turnover of this scale has important implications for natural resource management. Newer and longer term owners were very different in terms of their values, attitudes, knowledge, land use, and management practices. A substantial proportion of these new property owners are absentees, which further complicates natural resource management, and our view is that a "business as usual" approach to the engagement of the new cohort of rural land managers is unlikely to be effective.
\end{abstract}

Key Words: amenity migration; Australia; property turnover; rural land use change

\section{INTRODUCTION}

The high and rising mean age of farmers in Australia (over 55 years in many areas) suggests that property transfers are likely to increase as farmers approach normal retirement age (Peterson and Coppock 2001 cited in Barr 2003, Mendham and Curtis 2010). There is also evidence that the expectation of intergenerational transfer of properties is diminishing (Barr 2000, 2004). These trends suggest there is considerable potential for high levels of rural property turnover and that many properties will be purchased by non-family members (Mendham and Curtis 2010).

In areas where farming is profitable and land costs reflect the underlying value of agricultural production, farmers are often purchasing properties from retiring neighbors (Gow and Stayner 1992, Lockie et al. 2006). The net effect is a decline in rural populations and industries, where a small number of producers are now responsible for the bulk of production (Barr 2003). In other rural landscapes where farming is less profitable, there are attractive natural and cultural assets, and there is proximity to metropolitan areas, there is in-migration and subdivision of rural land (Hugo 1994, Argent 2002, Smailes 2002, Burnley and Murphy 2004, Argent et al. 2007). Similar trends have been identified across North America and Europe, and are linked to wider global forces that are restructuring rural landscapes (McGranahan 1999, Rudzitis 1999, Wilson 2001, Walford 2003, Frentz et al. 2004, Gosnell and Abrams 2009). While this research drew upon frameworks that examined rural restructuring, our focus is on exploring the extent and impact of rural property turnover on natural resource management (NRM).
Several studies have been conducted with the goal of identifying generalizable differences between new migrants and longer term owners in terms of their values, attitudes, knowledge, and land management practices (Nelson 1997, Jones et al. 2003, Burnley and Murphy 2004, Jackson-Smith et al. 2005, Gosnell et al. 2007, Yung and Belsky 2007). It appears that an important difference between new and longer term owners is a production or consumption orientation (Bohnet et al. 2003, Loeffer and Ernst 2007). Some of these studies have grouped landholders into different categories, and these approaches provide some useful insights (Kluender and Walkingstick 2000, Kendra and Hull 2005, Maller et al. 2007). For example, Gentner and Tanaka (2002) established that hobbyists, or those not dependent on the ranch for income, comprised more than $50 \%$ of all ranch owners in the western United States. A number of studies have established that new owners often express more interest in conservation and hold value orientations conducive to improved environmental management (Bohnet et al. 2003, Jones et al. 2003, JacksonSmith et al. 2005, Travis 2007). However, they may not necessarily have the skills or knowledge required to manage their land in ways that are consistent with those values (Klepeis et al. 2009).

There has been little Australian or international research that has examined rural property turnover. The exceptions include Gosnell et al.'s (2006) study around the Greater Yellowstone National Park in the USA. This study indicated that $23 \%$ of all land studied (> 162 ha [400 acres]) had changed hands in the past decade, with some counties experiencing turnover of $50 \%$. The level of property turnover was assessed as signifying

\footnotetext{
${ }^{1}$ National Centre for Groundwater Research and Training, ${ }^{2}$ Institute for Land, Water and Society, Charles Sturt University, ${ }^{3}$ School of Environmental Sciences, Charles Sturt University
} 
an important transition not seen before-from traditional ranchers to a diverse set of amenity buyers. Huntsinger et al. (1997) reported high levels of property turnover (35\%) and subdivision in a Californian hardwood rangeland between 1985 and 1992. Until recently, Australian studies have focused on the broad composition, size, source, and destination of migration flows by using census data rather than localityoriented research on the changing use of rural space at the destinations of migrants (Holmes 2006, Argent et al. 2007). McCarthy (2008) called for research that examined the ecological effects of rural change as newcomers change patterns of land use and actively or passively transform the landscape. Responding to these challenges, Mendham and Curtis (2010) predicted substantial and increased rates of rural property turnover of up to $50 \%$ in one Australian NRM region in the next decade (of properties greater than 10 ha [25 acres]), and began to examine the implications of that change for land use and management. We build upon that research by identifying trends in rural property turnover in two Australian regions and by exploring the implications of those trends for land use and management.

\section{METHODS}

We gathered primary and secondary data at the NRM region and district scales. Two NRM regions and two districts (one within each region) were selected (Fig. 1). The Corangamite NRM region $\left(13,340 \mathrm{~km}^{2}\right)$ is located to the west of the city of Melbourne in Victoria, Australia. The region has a diverse economy, with employment predominantly in the manufacturing and service sectors. Although agriculture and forestry employ only $5 \%$ of the workforce, land use is dominated by agriculture. Proximity to Melbourne and highly attractive coastal and forested areas are drawcards for new residents. However, in the farming districts further north and west of Melbourne, populations are declining. In contrast, the Wimmera NRM region $\left(23,500 \mathrm{~km}^{2}\right)$ is primarily a broadacre farming region largely cleared of native vegetation to establish agriculture. The region encompasses amenity landscapes, including areas around the Grampians National Park and along the Wimmera River, as well as around large freshwater lake systems.

We drew upon data from regional surveys of 1000 rural landholders in the Corangamite (Curtis et al. 2006) and Wimmera regions (Curtis et al. 2008a), and built upon our previously published research (Mendham and Curtis 2010). We achieved a response rate of $57 \%$ for the Corangamite survey and $56 \%$ for the Wimmera survey. Curtis et al. (2005) provide a detailed explanation of the mail out and collaborative research process undertaken. Local governments provided access to their ratepayer lists, and these were used to compile a database of all rural properties greater than 10 ha. We were interested primarily in larger rural properties that have greater conservation potential as intact units. The mail out process followed a modified Dillman (1978) total design method.
Surveys were posted with a cover letter, and reminder cards were sent in successive weeks. A second mail out to those who had not responded was conducted, followed by final reminder cards.

Fig. 1. The Wimmera and Corangamite natural resource management (NRM) regions, Victoria, Australia.

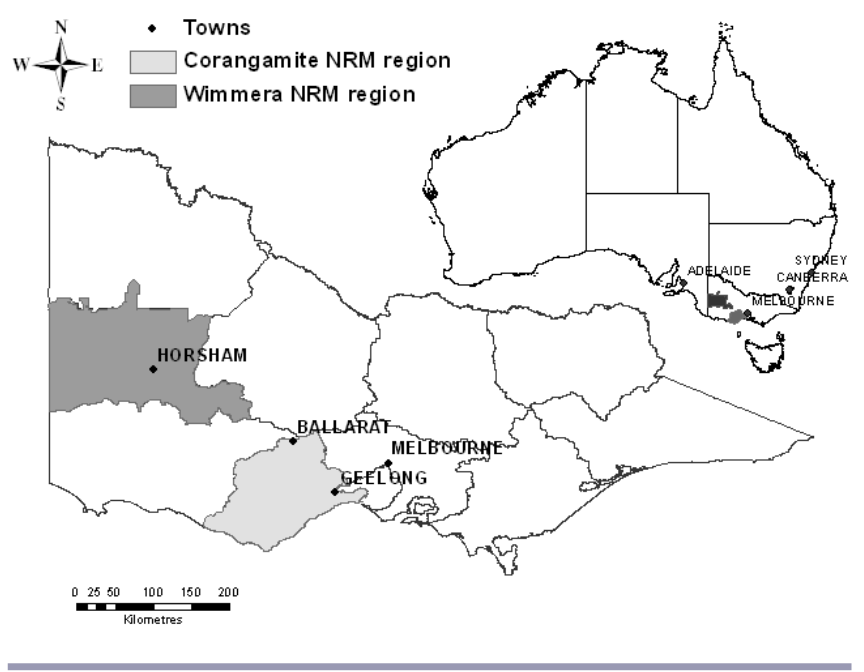

As part of the analysis of the regional data sets, the research team explored the differences between new (respondents with less than 10 years of property ownership) and longer term landholders at the regional level. A 10-year threshold was employed because there was not an obvious migration wave; the 10-year threshold would enable comparisons with many international studies; property sales data for a 10-year period prior to the surveys were available; and this division provided a larger sample of survey respondents than would a lower threshold.

The survey was intended to gather information on landholders' management practices, long-term plans, values, assessment of issues, and knowledge of NRM topics. Six-point Likert scale response options were employed (1-not applicable, 2-not important, 3-minimal importance, 4-some importance, 5 -important, 6-very important). "Not applicable" responses were removed from the calculation of means and medians and tests for significance. The statistical tests used were the nonparametric Kruskal-Wallis Rank Sum test for continuous and Likert scale data and Pearson's Chi-square test for count and categorical data.

One district in each NRM region was selected for qualitative semi-structured interviews with key informants, including landholders, real estate agents, and NRM professionals. The district selected in the Wimmera NRM region had a strong agricultural focus, while the district in the Corangamite region was more complex: it was experiencing amenity migration 
Table 1. Property turnover trends: Corangamite and Wimmera natural resource management regions.

\begin{tabular}{lccccc}
\hline \hline Region & $\begin{array}{c}\text { Turnover } \\
1995-2005\end{array}$ & Predicted turnover & $\begin{array}{c}\text { Land area predicted to } \\
\text { turnover }\end{array}$ & $\begin{array}{c}\text { Owned property }<10 \\
\text { yrs }\end{array}$ & $\begin{array}{c}\text { Median length of } \\
\text { residence }\end{array}$ \\
\hline Wimmera & $22 \%$ & $45 \%(2008-2018)$ & $50 \%$ & $15 \%$ & $45 \mathrm{yrs}$ \\
Corangamite & $25 \%$ & $50 \%(2006-2016)$ & $52 \%$ & $19 \%$ & $34 \mathrm{yrs}$ \\
\hline
\end{tabular}

while also encompassing some agricultural areas. The 42 semi-structured interviews focused on identifying changes occurring over time on individual holdings, and exploring the influence of longer term drivers on property management and turnover. In the first instance, informants were identified using the research teams' professional networks. Subsequent selections were made using the snowball method, and considerable effort was made to ensure a cross-section of landholders, including new, longer term, and absentee owners, was obtained. Interviews lasted from one to four hours and were tape recorded and transcribed verbatim. The interviews were analyzed thematically using NVivo version 7.

\section{RESULTS}

\section{Increased rates of property turnover}

Analysis of property sales data for Victoria indicated that approximately one-quarter of properties greater than 10 ha in the two regions had been sold at least once between 1995 and 2005. Using survey data on respondents' age and future intentions, and Australian life expectancy tables, the research team predicted close to double those rates of turnover for both regions in the subsequent decade (Table 1). Given that more than $80 \%$ of survey respondents in both regions had owned their properties for more than 10 years, and the median length of residence was 34 years in Corangamite and 45 years in Wimmera (Table 1), it seems that the predicted property turnover represents a dramatic change in the pre-existing ownership pattern, an assessment confirmed by analysis of Victorian State Government property sales data, which indicated that over the past 10 years, $42 \%$ of new owners in Wimmera and $61 \%$ in Corangamite lived outside the local government area where the purchased property was located.

\section{New and longer term owners are different}

We used our survey findings to explore the extent to which this property turnover might result in changes in the characteristics of landholders and their land use and management. Most of the land ownership change over the past 10 years involved the replacement of longer term owners, many of them farmers, with a new cohort of non-local landholders who were largely independent from agriculture. Newer and longer term owners were different with regards to values, knowledge, sources of information, concerns about issues, and to some extent, land use and management practices.
Social and farming variables

New owners were significantly different from longer term owners on a range of social and farming variables. Newer owners were less likely to be farmers, to be members of Landcare or commodity groups, to report an on-property profit, and to indicate they had family interested in taking on the property. Newer owners were also more likely to operate smaller properties and to work longer hours off-property. A substantial proportion of newer owners were absentee owners (Table 2).

\section{Values, assessment of issues, and knowledge}

Longer term owners were more likely to value their property for the economic and social outcomes linked to farming. On the other hand, newer landholders were more likely to value their properties for environmental reasons and for recreation. There was a significant difference between the two groups on the statement measuring commitment to a stewardship ethic based on the concept that "reduced production in the shortterm is justified where there are long-term benefits to the environment" (Table 3).

Newer owners reported higher levels of concern about environmental issues and were more likely to agree with statements that proposed limits to landholder property rights, including those involving a duty of care for biodiversity (Table 3 ). Newer and longer term owners self-reported significantly different levels of knowledge on a number of survey items, which suggested that newer owners were less knowledgeable about many topics related to sustainable agriculture but were more knowledgeable about topics related to biodiversity conservation (Table 4).

\section{Land use}

While most survey respondents were involved in dryland farming, there were some significant differences in the land use of new and longer term owners (Table 5). As might be expected given the occupational differences outlined earlier, longer term owners were more likely to be involved in broadacre cropping, sheep farming, and dairy (in the Corangamite)_-industries that are more intensive and require a substantial commitment of time, investment in equipment, and sophisticated management skills. On the other hand, newer landholders were more likely to have some part of their property placed under a conservation convent, were more likely to plan to place some part of their property under a 
Table 2. Comparing newer (Wimmera region: $n=55-73$; Corangamite region: $n=83-91$ ) and longer term (Wimmera region: $n=311-404$; Corangamite region: $n=311-404)$ landholders: social and farming variables. $(n$ denotes the number of respondents. Each item had a different number of respondents owing to missing values; these are indicated by the ranges in $n$.)

\begin{tabular}{|c|c|c|c|c|c|c|}
\hline \multirow[b]{2}{*}{ Social and farming variables } & \multicolumn{3}{|c|}{ Wimmera natural resource management region } & \multicolumn{3}{|c|}{ Corangamite natural resource management region } \\
\hline & New & Longer term & $P$ value & New & Longer term & $P$ value \\
\hline Median property size & 145 ha & 722 ha & $<0.001$ & 41 ha & 140 ha & $<0.001$ \\
\hline Farmer by occupation & $35 \%$ & $73 \%$ & $<0.001$ & $23 \%$ & $61 \%$ & $<0.001$ \\
\hline Mean hours worked on property/week & $29 \mathrm{hrs}$ & $42 \mathrm{hrs}$ & $<0.001$ & $27 \mathrm{hrs}$ & $40 \mathrm{hrs}$ & $<0.001$ \\
\hline Mean days worked off-property/year & 101 days & 58 days & 0.006 & 155 days & 67 days & $<0.001$ \\
\hline Returned a net on-property profit & $17 \%$ & $38 \%$ & 0.002 & $35 \%$ & $68 \%$ & $<0.001$ \\
\hline Property is principal place of residence & $58 \%$ & $82 \%$ & $<0.001$ & $61 \%$ & $81 \%$ & $<0.001$ \\
\hline Member of Landcare & $17 \%$ & $43 \%$ & $<0.001$ & $24 \%$ & $37 \%$ & 0.027 \\
\hline Member of a commodity group & $8 \%$ & $27 \%$ & 0.004 & $13 \%$ & $20 \%$ & 0.173 \\
\hline Intend to pass the property on in the family & $49 \%$ & $61 \%$ & 0.097 & $36 \%$ & $53 \%$ & 0.01 \\
\hline
\end{tabular}

covenant, and were more likely to be engaged in viticulture (in the Corangamite) or alternative forms of livestock (Table $5)$.

\section{Information sources}

There were significant differences between the two groups regarding their sources of NRM information. New owners were more likely to use the Internet, while longer term owners were more likely to use traditional sources of information, such as Landcare and commodity groups (Table 6).

\section{Land management}

The survey included items that sought information about the implementation of practices currently recognized as bestpractice farming (currently recommended practices [CRPs]) or those practices expected to lead to improvements in the condition of soil, water, and native vegetation. Comparisons of CRP implementation by new and longer term owners were undertaken in a way to avoid bias that might develop given that longer term owners own much larger properties and that there were differences in the types of land use between the two groups. Only those respondents who undertook a specific land use (e.g., grazing stock) were included in comparisons on the uptake of related CRPs (e.g., fencing native bush/ grassland to manage stock access), and comparisons were made on the basis of whether CRPs were reported as being undertaken rather than on the extent of activity. All statements that sought information about the implementation of CRPs were time bound (e.g., past 12 months, last five years, period of management) to reduce the effect of time on implementation and to reduce bias towards longer periods of ownership.

In the Wimmera region, there was only one significant difference in the implementation of CRPs by new and longer term owners: longer term owners were more likely to be involved in sowing perennial pasture or lucerne ( $38 \%$ of longer term owners compared to $24 \%$ of new owners, $p=0.030$ ). In the Corangamite region, there was also a difference between the two groups in the establishment of perennial pasture $(63 \%$ of longer term owners compared to $33 \%$ of newer owners, $p$ $<0.001)$. Contrary to expectations, newer owners in the Corangamite region were less likely to plant trees and shrubs (59\% of new owners compared to $78 \%$ of longer term owners, $p<0.001)$. It appears that newer and longer term landholders were implementing most CRPs at similar levels.

Logistic regression was conducted to further identify the influence of length of property ownership on the implementation of CRPs where there was a significant difference between the two groups. CRPs were treated as dichotomous dependent variables (those who had adopted the practice and those who had not). This analysis failed to identify a significant positive relationship between length of ownership and those CRPs. At the same time, factors related to farming as an occupation, and indirectly to length of ownership (attitudes, values, involvement in local networks, longer hours worked on property, on-property profitability, and greater knowledge of NRM) were significantly related to CRP implementation (Mendham and Curtis 2010).

\section{District scale: land use and management change}

Statistical analysis of survey data suggested that trends in property ownership were linked to changes in land use in the regions and, to a lesser extent, the implementation of CRPs. We acknowledge that there are other important drivers of land use and management change, including government policy, climate, environmental movements, global market conditions, and technology. Our focus was on the impact of property turnover. Analyses of survey data indicated that most new owners were non-farmers, and while logistic regression did not highlight length of ownership as a factor in the implementation of CRPs, there were significant relationships with others factors related to farming as an occupation. Analysis of the interview transcripts suggested that occupational identity was more important than the period of ownership as an influence on management practices. While at the regional scale there was a clear division between new and longer term owners in terms of occupation, each group was 
Table 3. Comparison of newer (Wimmera region: $n=43-68$; Corangamite region: $n=89-90$ ) and longer term (Wimmera region: $n=176-388$; Corangamite region: $n=358-363$ ) landholders: values attached to property, assessment of issues, and value orientation. ( $n$ denotes the number of respondents. Each item had a different number of respondents owing to missing values; these are indicated by the ranges in $n$.)

\begin{tabular}{|c|c|c|c|c|c|c|}
\hline \multirow[b]{2}{*}{ Topic } & \multicolumn{3}{|c|}{ Wimmera natural resource management region } & \multicolumn{3}{|c|}{ Corangamite natural resource management region } \\
\hline & New & Longer term & $P$ value & New & Longer term & $P$ value \\
\hline \multicolumn{7}{|l|}{ Values } \\
\hline $\begin{array}{l}\text { My property contributes to the environmental health } \\
\text { of the district }\end{array}$ & 4.06 & 3.76 & 0.022 & 3.5 & 3.37 & 0.220 \\
\hline $\begin{array}{l}\text { Sense of accomplishment from building/maintaining } \\
\text { a viable business }\end{array}$ & 3.95 & 4.12 & 0.352 & 3.59 & 3.92 & 0.016 \\
\hline A place for recreation & 3.77 & 3.23 & 0.001 & 3.65 & 3.13 & $<0.001$ \\
\hline $\begin{array}{l}\text { Native vegetation on my property provides habitat for } \\
\text { native animals }\end{array}$ & 3.69 & 3.32 & 0.013 & 3.46 & 3.09 & 0.023 \\
\hline $\begin{array}{l}\text { Sense of accomplishment from producing food/fiber } \\
\text { for others }\end{array}$ & 3.37 & 3.7 & 0.136 & 3.07 & 3.55 & $<0.001$ \\
\hline \multicolumn{6}{|l|}{ Assessment of issues } & $<0.001$ \\
\hline $\begin{array}{l}\text { Getting the balance right between water for the } \\
\text { environment, agriculture, and recreation }\end{array}$ & 4.39 & 4.05 & 0.013 & Not asked & - & - \\
\hline $\begin{array}{l}\text { Impact of reduced water flows on the long-term } \\
\text { health of rivers/streams/wetlands }\end{array}$ & 4.30 & 3.89 & 0.009 & Not asked & - & - \\
\hline Dryland salinity threatening water quality & 4.05 & 3.35 & $<0.001$ & 3.05 & 2.68 & 0.042 \\
\hline $\begin{array}{l}\text { Decline in soil health (e.g., declining fertility or } \\
\text { structure) }\end{array}$ & 4.05 & 3.37 & $<0.001$ & 3.11 & 2.75 & 0.024 \\
\hline $\begin{array}{l}\text { The effect of increased ground and surface water } \\
\text { extraction }\end{array}$ & 4.05 & 3.49 & $<0.001$ & Not asked & - & - \\
\hline Farming practices contributing to erosion & 3.78 & 2.98 & $<0.001$ & Not asked & - & - \\
\hline $\begin{array}{l}\text { Nutrient and chemical runoff affecting water quality } \\
\text { in rivers/streams/wetlands }\end{array}$ & 3.74 & 2.99 & $<0.001$ & 3.20 & 2.81 & 0.022 \\
\hline $\begin{array}{l}\text { Dryland salinity threatening the long-term productive } \\
\text { capacity of land }\end{array}$ & 3.50 & 3.03 & 0.008 & 3.07 & 2.58 & 0.006 \\
\hline $\begin{array}{l}\text { Loss of habitat for birds and animals due to the loss } \\
\text { of paddock trees }\end{array}$ & 3.60 & 2.95 & $<0.001$ & Not asked & - & - \\
\hline $\begin{array}{l}\text { Uncertain, low returns limiting capacity to invest on } \\
\text { property }\end{array}$ & 3.28 & 3.72 & 0.022 & Not asked & - & - \\
\hline $\begin{array}{l}\text { Planting out large areas of the Wimmera farmland to } \\
\text { native bush is justified }\end{array}$ & 3.26 & 2.59 & $<0.001$ & Not asked & - & - \\
\hline $\begin{array}{l}\text { Loss of habitat due to clearing of native vegetation in } \\
\text { our local district }\end{array}$ & Not asked & - & - & 3.11 & 2.43 & $<0.001$ \\
\hline \multicolumn{7}{|l|}{ Stewardship and duty of care } \\
\hline $\begin{array}{l}\text { Reduced production in the short-term is justified } \\
\text { where there are long-term benefits to the environment } \\
\text { (stewardship value) }\end{array}$ & 4.71 & 4.23 & $<0.001$ & 3.64 & 3.32 & 0.006 \\
\hline $\begin{array}{l}\text { It is fair that the wider community asks landholders } \\
\text { to manage their land in ways that do not cause } \\
\text { foreseeable harm to the environment (duty of care) }\end{array}$ & 4.97 & 4.33 & $<0.001$ & 3.76 & 3.29 & $<0.001$ \\
\hline $\begin{array}{l}\text { In future, landholders should expect to be legally } \\
\text { responsible for managing their land in ways that do } \\
\text { not cause foreseeable harm to the environment (duty } \\
\text { of care) }\end{array}$ & 4.46 & 3.84 & $<0.001$ & Not asked & - & - \\
\hline
\end{tabular}

heterogeneous and included non-farmers, farmers, "adopters," and "non-adopters." The qualitative data presented here provides further insight into these trends.

There was a trend to new, non-farming landholders purchasing rural properties in the Corangamite case study district. In these situations, land often moved from productive to nonproductive uses, with properties managed for their conservation or recreation value. Some examples of the changes implemented by new owners included creating a wetland area or revegetating most of the property. For many non-farmers, an interest in wildlife was often an important motivation for purchasing the property and remained an important influence on land use and management: "When we first came here hardly a bird—no trees. Since we've been here koalas have moved back into the bush." Several interviewees expressed a strong stewardship ethic and identified it as a driver of the improvements they made to their properties. 
Table 4. Comparing newer (Wimmera region: $n=66-70$; Corangamite region: $n=85-89$ ) and longer term (Wimmera region: $n=358-398$; Corangamite region: $n=315-359$ ) landholders: knowledge. ( $n$ denotes the number of respondents. Each item had a different number of respondents owing to missing values; these are indicated by the ranges in $n$.)

\begin{tabular}{|c|c|c|c|c|c|c|}
\hline \multirow[b]{2}{*}{ Knowledge topic } & \multicolumn{3}{|c|}{ Wimmera natural resource management region } & \multicolumn{3}{|c|}{ Corangamite natural resource management region } \\
\hline & New & Longer term & $P$ value & New & Longer term & $P$ value \\
\hline $\begin{array}{l}\text { Paddock trees play an important role by providing a } \\
\text { place for native animals to shelter and feed }\end{array}$ & 4.16 & 3.77 & $<0.001$ & Not asked & - & - \\
\hline $\begin{array}{l}\text { Clearing of native vegetation has substantially } \\
\text { reduced the number and variety of native plants and } \\
\text { animals in this district }\end{array}$ & 3.71 & 3.31 & 0.009 & 3.53 & 3.04 & $<0.001$ \\
\hline $\begin{array}{l}\text { Grazing strategies to manage paddock ground cover } \\
\text { to minimize soil erosion }\end{array}$ & 3.21 & 3.59 & 0.019 & Not asked & - & - \\
\hline How to collect soil test samples & 2.94 & 3.32 & 0.009 & Not asked & - & - \\
\hline $\begin{array}{l}\text { How to prepare a farm or property plan that allocates } \\
\text { land use according to different land classes }\end{array}$ & 2.71 & 3.06 & 0.032 & Not asked & - & - \\
\hline $\begin{array}{l}\text { The benefits of ground cover on grazing or cropping } \\
\text { paddocks to maintain or improve soil health }\end{array}$ & Not asked & - & - & 3.00 & 3.32 & 0.011 \\
\hline $\begin{array}{l}\text { In most cases, the benefits of de-rocking outweigh } \\
\text { the environmental costs, such as the loss of native } \\
\text { grasslands }\end{array}$ & Not asked & - & - & 3.07 & 3.33 & 0.033 \\
\hline $\begin{array}{l}\text { The benefits of pastures in crop rotation in } \\
\text { maintaining soil health }\end{array}$ & Not asked & - & - & 3.14 & 3.44 & 0.003 \\
\hline $\begin{array}{l}\text { Legislation about the on-property handling and } \\
\text { storage of chemicals }\end{array}$ & Not asked & - & - & 2.79 & 3.40 & $<0.001$ \\
\hline How to interpret results from soil testing & Not asked & - & - & 2.61 & 3.09 & $<0.001$ \\
\hline How to recognize the signs of salinity & Not asked & - & - & 2.91 & 3.21 & 0.003 \\
\hline How to identify new or emerging weed species & Not asked & - & - & 2.81 & 3.14 & 0.002 \\
\hline Ability to identify acidic soils in this district & Not asked & - & - & 2.48 & 2.93 & $<0.001$ \\
\hline How to interpret results for water quality testing & Not asked & - & - & 2.24 & 2.63 & 0.003 \\
\hline $\begin{array}{l}\text { The processes leading to soil acidification in this } \\
\text { district }\end{array}$ & Not asked & - & - & 2.06 & 2.51 & $<0.001$ \\
\hline $\begin{array}{l}\text { The major natural resource management strategies of } \\
\text { the Corangamite Catchment Management Authority }\end{array}$ & Not asked & - & - & 1.83 & 2.29 & $<0.001$ \\
\hline
\end{tabular}

In some cases, substantial changes to property management were implemented by non-farming landholders, particularly when taking over from an older, absentee farmer who had been disengaging from agriculture over a number of years. The changes included fence erecting, weed and pest animal control, erosion remediation, and tree planting. In these situations, the landholders were challenged by the poor state of the property at the time of purchase, which also acted as a driver for the improvements made.

However, as suggested by the survey data, newer owners were a heterogeneous group. Interviews highlighted the diverse nature of new, non-farming landholders, from those actively practicing stewardship to those inactive in management. In contrast to those practicing active stewardship, others had limited involvement in property management. One new owner said that most of the time they were on the property was spent on the house and garden. Another, who agisted land to a neighbor, was focused on their other investment properties. As much as it was clear that many new owners had a vision for their property, this interviewee spoke about the time it was taking him to decide what he would like to do with his property, to build up a vision, to amass sufficient experience to take action, and to tap into local networks.
Some longer term landholders referred to "blockies," or small, lifestyle-oriented landholders, and described areas where properties and livestock were being poorly managed, including instances where it appeared that the "block" had been purchased to run a pony or motorbike. At the same time, interviewees acknowledged that longer term, "traditional" farmers were a diverse group, some of whom were not undertaking "best practices," and that some new owners were highly motivated and had improved on the previous management.

Time constraints were mentioned by all non-farming landowners (this was compounded for absentee landholders), and all spoke of the length of time it took to learn about property management. All non-farmers mentioned "having a lot to learn" or "learning from our mistakes." Many (including both those actively and passively managing their properties) spoke of the need to actively seek information, "....the forthcoming information wasn't there. You had to do the investigation." In several cases, having a helpful neighbor to provide advice or equipment was highly valued. In another case, an interviewee was not "taken seriously" by longer term farming neighbors, despite making substantial on-property improvements. Lack of experience could be compounded by receiving bad advice 
Table 5. Comparing newer (Wimmera region: $n=68-79$; Corangamite region: $n=82-85$ ) and longer term (Wimmera region: $n=314-323$; Corangamite region: $n=331-342$ ) landholders: land use. ( $n$ denotes the number of respondents. Each item had a different number of respondents owing to missing values; these are indicated by the ranges in $n$.)

\begin{tabular}{|c|c|c|c|c|c|c|}
\hline \multirow[b]{2}{*}{ Land use } & \multicolumn{3}{|c|}{ Wimmera natural resource management region } & \multicolumn{3}{|c|}{ Corangamite natural resource management region } \\
\hline & New & Longer term & $P$ value & New & Longer term & $P$ value \\
\hline Broadacre cropping & $46 \%$ & $78 \%$ & $<0.001$ & $16 \%$ & $29 \%$ & 0.027 \\
\hline Sheep for meat & $52 \%$ & $70 \%$ & 0.04 & Not asked & - & - \\
\hline Sheep for wool & $42 \%$ & $68 \%$ & $<0.001$ & Not asked & - & - \\
\hline Sheep farming & Not asked & - & - & $28 \%$ & $47 \%$ & 0.003 \\
\hline Plan for a conservation covenant & $20 \%$ & $11 \%$ & 0.06 & $18 \%$ & $11 \%$ & 0.002 \\
\hline Conservation covenant & $17 \%$ & $9 \%$ & 0.02 & $14 \%$ & $7 \%$ & 0.002 \\
\hline Alternative forms of livestock & $16 \%$ & $7 \%$ & 0.016 & $14 \%$ & $7 \%$ & 0.036 \\
\hline Viticulture & Not asked & - & - & $12 \%$ & $5 \%$ & 0.029 \\
\hline Beef & $16 \%$ & $16 \%$ & 0.908 & $59 \%$ & $52 \%$ & 0.338 \\
\hline Dairy & $0 \%$ & $1 \%$ & 0.255 & $11 \%$ & $24 \%$ & 0.010 \\
\hline
\end{tabular}

from contractors, as one interviewee highlighted, "We knew it was too green to bale-we knew but because we were not experienced enough and he did it without telling us, we felt powerless with the result."

There were also examples of non-farmers undertaking a range of agricultural enterprises on their properties, including sheep and beef grazing, but also innovative enterprises such as alpacas, organic lucerne, furniture timber, and organic garlic. These endeavors were framed as part of a lifestyle rather than motivated by production and profit. Some interviewees developed an agricultural venture by chance, while others purchased a property in order to pursue agriculture, sometimes as an interest during retirement. Owning a larger property (4081 ha [100-200 acres]) seemed to be associated with "wanting to do something productive." Some interviewees expressed a desire to "make their farm pay" as something that might "pay the school fees" or perhaps provide a small profit to invest back in the property, "Bibs and bobs starting to pay for itself -we could buy the tractor. If you can do that, your income from the city is not too exhausted." Several of these interviewees described how they were able to approach things differently from farmers by planting trees or using organic fertilizer on their small properties, and subsidizing activities with off-property income.

NRM agency interviewees acknowledged the opportunity that property turnover represented because “...they've got other priorities, but if they want to do something, they've got the resources." The need to tailor engagement to new, nonfarming landholders was recognized: "They have only got the weekends. Got kids, sport, and all that sort of stuff...their property becomes their haven but not necessarily the most important thing they do."

In farming districts, new landholders were often farmers. While change in property ownership did not result in a change to non-farming use, property turnover often resulted in onproperty investment. The extent of investment required depended on the state of the property at the time of purchase, and included updating irrigation systems, improving pastures, and planting trees for windbreaks. Many felt turnover often resulted in poorer managers, or those who had "had enough" exiting the industry or turning to off-farm income sources, while others "treated it as a business" and faced the next set of challenges. Older farmers nearing retirement were expected to sell. Interviewees (both of the younger generation and those nearing the end of their careers) felt successors were usually better educated, were often more involved in innovative groups, were more highly trained, were more widely traveled and thus exposed to different ideas, and brought an interest and new set of skills related to cropping (driven by technological advances and climatic conditions suited to cropping, attractive market prices for grain, and lifestyle benefits, such as the ability to take holidays given freedom from managing stock). While many of the current generation of farmers were progressive, interviewees felt there was a consistent trend to the next generation of farmers having a more professional approach to farming, business, and finance. One interviewee who had recently taken over management from his father stated, "I am also more focused on planning and budgeting," and "There was no real planning. These were kids who grew up during the wool boom-there was a heap of money when they were younger...never seemed to be a focus on planning... and now, there is a lot of focus on productivity. All of the courses you do." Having not lived through prosperous market conditions such as the minimum price for wool and the wool boom (excellent returns for wool driven by the Korean War and other factors), the new generation treated farming as a business rather than as a lifestyle: "It's been run as a business a lot more now...I think the younger ones that have been through the courses are the farmers of the future. They just have to be to survive."

\section{DISCUSSION}

The prediction of large scale property turnover in the two Victorian regions is consistent with Barr's (2003) prediction 
Table 6. Comparing newer (Wimmera region: $n=68-79$; Corangamite region: $n=82-85$ ) and longer term (Wimmera region: $n=314-323$; Corangamite region: $n=331-342$ ) landholders: information sources. ( $n$ denotes the number of respondents. Each item had a different number of respondents owing to missing values; these are indicated by the ranges in $n$.)

\begin{tabular}{|c|c|c|c|c|c|c|}
\hline \multirow[b]{2}{*}{ Information sources } & \multicolumn{3}{|c|}{ Wimmera natural resource management region } & \multicolumn{3}{|c|}{ Corangamite natural resource management region } \\
\hline & New & Longer term & $P$ value & New & Longer term & $P$ value \\
\hline Newspapers & $65 \%$ & $83 \%$ & 0.002 & $65 \%$ & $83 \%$ & 0.001 \\
\hline Catchment Management Authority & $42 \%$ & $55 \%$ & 0.1 & $33 \%$ & $48 \%$ & 0.014 \\
\hline Landcare group & $40 \%$ & $57 \%$ & 0.013 & $39 \%$ & $54 \%$ & $<0.001$ \\
\hline Extension officers & $30 \%$ & $27 \%$ & 0.747 & $14 \%$ & $26 \%$ & 0.030 \\
\hline Internet & $29 \%$ & $19 \%$ & 0.102 & $43 \%$ & $18 \%$ & $<0.001$ \\
\hline Victorian Farmers Federation & $11 \%$ & $33 \%$ & $<0.001$ & $11 \%$ & $32 \%$ & $<0.001$ \\
\hline Training courses & $8 \%$ & $14 \%$ & 0.257 & $17 \%$ & $8 \%$ & 0.027 \\
\hline Universities & $5 \%$ & $5 \%$ & 0.981 & $14 \%$ & $5 \%$ & 0.006 \\
\hline
\end{tabular}

of farmer retirements in the period 2005-2015 based on his analysis of Australian census data. We extended our previous findings in the Corangamite NRM region by comparing them to the Wimmera region, which is more typical of landscapes focused on agricultural production, and the results suggest that substantial property turnover is occurring across a range of social landscapes. Our predictions of future turnover are also comparable with research findings in the USA and Britain that are associated with the retirement of the baby boomer cohort and amenity migration (Bohnet et al. 2003, Gosnell and Travis 2005, Gosnell et al. 2006).

Rural property turnover at the regional scale, particularly in the Corangamite region, but also in parts of the Wimmera, typically involved the replacement of farmers with a diverse group of non-farmers. Change in the occupational make-up of a region has been identified as a key element of property turnover in northern America (Gosnell and Travis 2005, Gosnell et al. 2006, Gosnell et al. 2007). In our study, new property owners were significantly different from longer term landholders in that they were more likely to value conservation over agricultural production, they self-reported lower levels of knowledge of land management, they were involved in different land uses, and they implemented different land management practices. These findings are consistent with international research which suggests that new owners are different from longer term owners in terms of their environmental attitudes, attitudes towards property rights and duty of care, values, and land management practices. The findings are also consistent with international research which highlights the conservation motivations of new owners and production-oriented goals of longer term owners (Bohnet et al. 2003, Jones et al. 2003, Jackson-Smith et al. 2005, Kendra and Hull 2005, Gosnell et al. 2007, Loeffer and Ernst 2007, Yung and Belsky 2007). Interviews revealed varying levels of involvement in NRM among newer owners. Findings from this research are consistent with those of Gill et al. (2010), who found a period of familiarization, shock at the magnitude of the task, focus on house and domestic space, testing and trying different approaches, and gradual machinery acquisition among newcomers. Additionally, a substantial proportion of newer owners in both regions are absentee owners. Rising levels of absenteeism in both regions represent an important change in social structure and will present challenges to NRM practitioner efforts to manage across property boundaries (e.g., Klepeis et al. 2009).

Of course, not all areas in our Australian research are experiencing in-migration of non-farmers. Our research indicates that property turnover can also be a catalyst for change in farming landscapes (Gow and Stayner 1992, Potter and Lobley 1992, Burton and Walford 2005). Our research suggests that much of the turnover in these production landscapes is due to farmer retirement, and that many of the new owners are also farmers, including, in some cases, the offspring of the previous owners, which has important implications for production landscapes. For instance, Potter and Lobley (1996) noted the catalytic effect of ownership changes in farming landscapes, or the "new blood effect," where new owners at the start of their farming careers are very innovative.

\section{CONCLUSIONS}

This research has established that substantial property turnover is likely to occur across a range of social landscapes in rural Australia. We have established that new landholders are different from previous owners and that those differences influence the landholders' investments in infrastructure, land use, and management practices. New owners are generally less experienced land managers, have less knowledge of NRM issues, spend less time on their properties, and are less engaged in traditional extension processes and NRM programs (e.g., Landcare). They also access information in ways that are different from the typical media used by NRM staff. Additionally, an increasing proportion of new owners are absentee owners. These landholders are unlikely to be on their property during the week. A "business-as-usual" approach involving appeals to landholders based on enhancing agricultural production and profits is unlikely to motivate the 
increasingly important cohort of newer owners who are nonfarmers.

While some NRM agencies have been grappling with these issues for some time (e.g., Hollier and Reid 2007, Curtis et al. 2008b, Curtis et al. 2010), there is evidence that other NRM agencies have not engaged with non-farming landholders who make up the majority of landowners in many catchments, and in some, own the largest proportion of critical environmental assets, such as river frontages and riparian areas (Curtis and Race 2012). These findings emphasize the need to evaluate the impact of NRM programs that are attempting to engage non-farming landholders. Similarly, Gosnell and Abrams (2009) have called for additional research into the ways demographic change will influence social-ecological systems and shape NRM governance.

New landholders' interest in the biodiversity value of their properties, combined with access to off-farm income, means they may represent a "lower cost" cohort for agencies with a conservation focus to engage, in that they have strong conservation values and are less concerned about property rights, and are seeking knowledge rather than access to money and/or resources. Given these potential cost savings, NRM agencies should consider the merits of returning to a one-onone extension model for these landholders. Non-farming landholders may not be on their property during the day or on weekends, which presents an additional challenge for extension staff, and agencies may need to rethink their approach. Linking newer owners with a small number of neighbors appeals as an effective approach, as many interviewees spoke of the value of such relationships. Strong neighboring relationships are also critical to landscape scale conservation efforts.

NRM agency staff should be proactive in identifying newer owners, making personal contact with them to identify their needs, values, and goals, and providing them with ways to engage with local networks and wider information sources, including through a high-quality website. Our advice is that NRM staff should meet with landholders soon after they purchase their property and attempt to work with them as they develop a vision and plan for their property. Many new owners are highly motivated and have a budget to implement onproperty improvements, but they will be seeking advice, and in some cases, access to equipment to conduct on-property work. There is the potential to identify new owners through regular reviews of local government ratepayer databases that are updated after property transfers and to arrange an interview soon after.

Responses to this article can be read online at: http://www.ecologyandsociety.org/issues/responses. php/5071

\section{Acknowledgments:}

The authors thank the Corangamite and Wimmera Catchment Management Authorities, the Victorian Valuer General, Simon McDonald and Charles Sturt University's Spatial Data Analysis Unit, and the survey respondents and interviewees who participated in this research.

\section{LITERATURE CITED}

Argent, N. 2002. From pillar to post? In search of the postproductivist countryside in Australia. Australian Geographer 33(1):97-114.

Argent, N., P. J. Smailes, and T. Griffin. 2007. The amenity complex: towards a framework for analysing and predicting the emergence of a multifunctional countryside in Australia. Geographical Research 45(3):217-232. http://dx.doi. org/10.1111/j.1745-5871.2007.00456.x

Barr, N. 2000. Structural change in Australian agriculture: implications for natural resource management. Department of Natural Resources and Environment, Victoria, Australia.

Barr, N. 2003. Future agricultural landscapes. Australian Planner 40(2):123-128. http://dx.doi.org/10.1080/0729368$\underline{2.2003 .9995268}$

Barr, N. 2004. The micro-dynamics of change in Australian agriculture 1976-2001. Australian Bureau of Statistics, Canberra, Australia.

Bohnet, I., C. Potter, and E. Simmons. 2003. Landscape change in the multi-functional countryside: a biographical analysis of farmer decision making in the English High Weald. Landscape Research 28(4):349-364. http://dx.doi. org/10.1080/0142639032000150112

Burnley, I., and P. Murphy. 2004. Sea change: movement from metropolitan to arcadian Australia. University of Australia, Sydney, Australia.

Burton, R. J. F., and N. Walford. 2005. Multiple succession and land division on family farms in the south east of England: a counterbalance to agricultural concentration? Journal of Rural Studies 21:335-347. http://dx.doi.org/10.1016/j. jrurstud.2005.04.004

Curtis, A., I. Byron, and J. MacKay. 2005. Integrating socioeconomic and biophysical data to underpin collaborative watershed management. Journal of the American Water Resources Association 41(3):549-563. http://dx.doi.org/10.1111/ j.1752-1688.2005.tb03754.x

Curtis, A., P. Cooke, S. McDonald, and E. Mendham. 2006. Corangamite regional social benchmarking survey 2006. Institute for Land, Water and Society, Charles Sturt University, Albury, Australia. 
Curtis, A., S. McDonald, E. Mendham, and R. Sample. 2008a. Understanding the social drivers for natural resource management in the Wimmera region. Institute for Land, Water and Society, Charles Sturt University, Albury, Australia.

Curtis, A., and D. Race. 2012. Management of riparian zones by rural landholders. Pages 69-82 in E. Lefroy, A. Curtis, A. Jakeman, and J. McKee, editors. Landscape logic: integrated science for landscape management. CSIRO Publishing, Melbourne, Australia.

Curtis, A., D. Race, R. Sample, and S. McDonald. 2008b. Management of water ways and adjoining land in the MidGoulburn River: landholder and other stakeholder actions and perspectives. Institute for Land, Water and Society, Charles Sturt University, Albury, Australia.

Curtis, A., R. Sample, S. McDonald, and N. Mazur. 2010. Landholder participation in the Loddon Stressed Rivers Program. A report to the North Central Catchment Management Authority. Institute for Land, Water and Society, Charles Sturt University, Albury, Australia.

Dillman, D. 1978. Mail and telephone surveys. John Wiley \& Sons, New York, USA.

Frentz, I. C., F. L. Farmer, J. M. Guldin, and K. G. Smith. 2004. Public lands and population growth. Society and Natural Resources 17(1):57-68.

Gentner, B. J., and J. A. Tanaka. 2002. Classifying federal public land grazing permittees. Journal of Range Management 55:2-11. http://dx.doi.org/10.2307/4003256

Gill, N., P. Klepeis, and L. Chisholm. 2010. Stewardship among lifestyle oriented rural landowners. Journal of Environmental Planning and Management 53(3):317-334. http://dx.doi.org/10.1080/09640561003612890

Gosnell, H., and J. Abrams. 2009. Amenity migration: diverse conceptualizations of drivers, socioeconomic dimensions, and emerging challenges. Geojournal 10.1007/s10708-10009-19295-10704. http://dx.doi.org/10.1007/s10708-009-9295-4

Gosnell, H., J. H. Haggerty, and P. A. Byorth. 2007. Ranch ownership change and new approaches to water resource management in southwestern Montana: implications for fisheries. Journal of the American Water Resources Association 43(4):990-1003. http://dx.doi.org/10.1111/ j.1752-1688.2007.00081.x

Gosnell, H., J. H. Haggerty, and W. R. Travis. 2006. Ranchland ownership change in the Greater Yellowstone Ecosystem, 1990-2001: implications for conservation. Society \& Natural Resources: an International Journal 19 (8):743-758. http://dx.doi.org/10.1080/08941920600801181
Gosnell, H., and W. R. Travis. 2005. Ranchland ownership dynamics in the Rocky Mountain West. Rangeland Ecology and Management 58(2):191-198. http://dx.doi.org/10.2111/1551-5028 (2005)58<191:RODITR > 2.0.CO;2

Gow, J., and R. Stayner. 1992. The process of farm adjustment: a critical review. Review of Marketing and Agricultural Economics 63(2):272-283.

Hollier, C., and M. Reid. 2007. Small lifestyle farms: improving delivery mechanisms for sustainable land management. Rural Industries Research and Development Corporation, Canberra, Australia.

Holmes, J. 2006. Impulses towards a multifunctional transition in rural Australia: gaps in the research agenda. Journal of Rural Studies 22(2):142-160. http://dx.doi.org/10.1016/j.

jrurstud.2005.08.006

Hugo, G. 1994. The turnaround in Australia: some first observations from the 1991 census. Australian Geographer 25(1):1-17. http://dx.doi.org/10.1080/00049189408703094

Huntsinger, L., L. Buttolph, and P. Hopkinson. 1997. Ownership and management changes on California hardwood rangelands: 1985 to 1992. Journal of Range Management 50 (4):423-430. http://dx.doi.org/10.2307/4003311

Jackson-Smith, D., U. Krueter, and R. S. Krannich. 2005. Understanding the multidimensionality of property rights orientations: evidence from Utah and Texas ranchers. Society \& Natural Resources: an International Journal 18:587-610. http://dx.doi.org/10.1080/08941920590959578

Jones, R., J. M. Fly, J. Talley, and H. K. Cordell. 2003. Green migration into rural America: the new frontier of environmentalism? Society \& Natural Resources: an International Journal 16(3):221-238. http://dx.doi. org/10.1080/08941920309159

Kendra, A., and B. Hull. 2005. Motivations and behaviors of new forest owners in Virginia. Forest Science 51(2):142-154.

Klepeis, P., G. Gill, and L. Chisholm. 2009. Emerging amenity landscapes: invasive weeds and land subdivision in rural Australia. Land Use Policy 26:380-392. http://dx.doi. org/10.1016/j.landusepol.2008.04.006

Kluender, R. A., and T. L. Walkingstick. 2000. Rethinking how nonindustrial landowners view their lands. Southern Journal of Applied Forestry 24(3):150-158.

Lockie, S., G. Lawrence, and L. Cheshire. 2006. Reconfiguring rural resource governance: the legacy of neoliberalism in Australia. Pages 29-43 in P. Cloke, T. Marsden, and P. H. Mooney, editors. Handbook of rural studies. Sage Publications, London, UK. http://dx.doi.org/10.4135/9781848608016. $\underline{\text { n3 }}$ 
Loeffer, R., and S. Ernst. 2007. Amenity migration in the U. S. Sierra Nevada. Geographical Review 97(1):67-88. http:// dx.doi.org/10.1111/j.1931-0846.2007.tb00280.x

Maller, C., R. Kancans, and A. Carr. 2007. Biodiversity and small landholders in peri-urban Australia. Bureau of Rural Sciences, Canberra, Australia.

McCarthy, J. 2008. Rural geography: globalizing the countryside. Progress in Human Geography 32(1):129-137. http://dx.doi.org/10.1177/0309132507082559

McGranahan, D. A. 1999. Natural amenities drive rural population change. U.S. Department of Agriculture, Washington, D.C., USA.

Mendham, E., and A. Curtis. 2010. Taking over the reins: trends and impacts of changes in rural property ownership. Society \& Natural Resources: an International Journal 23 (7):653-668. http://dx.doi.org/10.1080/08941920801998893

Nelson, P. 1997. Migration, sources of income, and community change in the nonmetropolitan Northwest. Professional Geographer 49(4):418-430. http://dx.doi. org/10.1111/0033-0124.00088

Potter, C., and M. Lobley. 1992. Ageing and succession on family farms: the impact on decision-making and land use. Sociologia Ruralis 32(2/3):317-334. http://dx.doi.org/10.1111/ j.1467-9523.1992.tb00935.x

Potter, C., and M. Lobley. 1996. The farm family life cycle, succession paths and environmental change in Britain's countryside. Journal of Agricultural Economics 47:172-190. http://dx.doi.org/10.1111/j.1477-9552.1996.tb00683.x

Rudzitis, G. 1999. Amenities increasingly draw people to the rural West. Rural Development Perspectives 14(2):23-28.

Smailes, P. J. 2002. From rural dilution to multifunctional countryside: some pointers to the future from South Australia. Australian Geographer 33(1):79-95. http://dx.doi. org/10.1080/00049180220125024

Travis, W. R. 2007. New geographies of the American West: land use and the changing patterns of place. Island Press, Washington, D.C., USA.

Walford, N. 2003. Productivism is allegedly dead, long live productivism. Evidence of continued productivist attitudes and decision-making in South-East England. Journal of Rural Studies 19(4):491-502. http://dx.doi.org/10.1016/S0743-0167 (03)00030-5

Wilson, G. A. 2001. From productivism to postproductivism... and back again? Exploring the (un)changed natural and mental landscapes of European agriculture. Transactions of the Institute of British Geographers 26(1):77102. http://dx.doi.org/10.1111/1475-5661.00007
Yung, L., and J. M. Belsky. 2007. Private property rights and community goods: negotiating landowner cooperation amid changing ownership on the Rocky Mountain Front. Society \& Natural Resources: an International Journal 20(8):689-703. http://dx.doi.org/10.1080/08941920701216586 